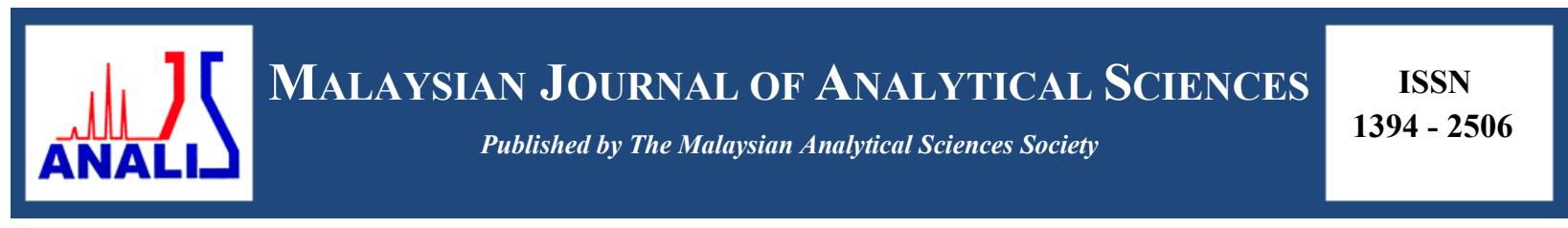

\title{
PREPARATION OF DATE SEED ACTIVATION FOR SURFACTANT RECOVERY
}

\author{
(Penyediaan Biji Kurma Teraktif Untuk Pemulihan Surfaktan) \\ Nurul' Ain Binti Jamion ${ }^{*}$, Nor Haziqah Binti Abd Hafiff, Nurul Huda Abd Halim, \\ Sheikh Ahmad Izzaddin Sheikh Mohd Ghazali, Jamil Mohamed Sapari \\ Department of Chemistry, Faculty of Applied Sciences, \\ Universiti Teknologi MARA, 72000 Kuala Pilah, Negeri Sembilan, Malaysia \\ *Corresponding author: ain7059@ns.uitm.edu.my
}

Received: 16 August 2016; Accepted: 5 September 2017

\begin{abstract}
Surfactants also known as surface-active agents are one of the water pollutants that can lead to the deterioration of the environment. In this study, activated carbon was prepared from date seeds (DAC) by using phosphoric acid as an activating agent. The activation process was carried out at $500{ }^{\circ} \mathrm{C}$ for two hours. DAC was characterized by Fourier-Transformed Infrared Spectrometer (FTIR), Field Emission Scanning Electron Microscopy (FESEM), Energy-Dispersive X-Ray Spectroscopy (EDX) and Nitrogen Adsorption at $77 \mathrm{~K}$. The BET surface area of DAC was $1187 \mathrm{~m}^{2} / \mathrm{g}$. The adsorption capacities of surfactants (CTAB and TX-100) were determined. This study showed that the adsorption capacity of CTAB $(23.0724 \mathrm{mg} / \mathrm{g})$ onto DAC was greater than TX-100 $(11.3868 \mathrm{mg} / \mathrm{g})$. The adsorption process between both surfactants onto DAC was done by physisorption through electrostatic forces. Thus, this study showed that the date seeds have a greater tendency to be microporous activated carbon and an adsorbent for surfactants recovery.
\end{abstract}

Keywords: activated carbon, phosphoric acid, date seed

\section{Abstrak}

Bahan aktif permukaan juga dikenali sebagai surfaktan adalah salah satu bahan pencemar air yang boleh membawa kepada kemerosotan alam sekitar. Dalam kajian ini, karbon teraktif telah disediakan daripada biji kurma (DAC) dengan menggunakan asid fosforik sebagai ejen pengaktifan. Proses pengaktifan telah dilakukan pada suhu $500{ }^{\circ} \mathrm{C}$ selama dua jam. Karbon teraktif (DAC) telah dicirikan oleh Spektroskopi Inframerah Transformasi Fourier (FTIR), Mikroskopi Medan Pancaran Imbasan Elektron (FESEM), Sebaran Tenaga Sinar-X (EDX) dan penjerapan gas nitrogen pada suhu 77 K. Luas permukaan BET kawasan DAC adalah $1187 \mathrm{~m}^{2} / \mathrm{g}$. Kapasiti penjerapan surfaktan (CTAB dan TX-100) telah dikaji. Kajian ini menunjukkan bahawa kapasiti penjerapan CTAB $(23.0724 \mathrm{mg} / \mathrm{g})$ pada DAC adalah lebih tinggi daripada TX-100 (11.3868 mg/g). Proses penjerapan antara bagi kedua-dua surfaktan DAC adalah secara penjerapan fizikal melalui daya elektrostatik. Oleh itu, kajian ini menunjukkan bahawa biji kurma mempunyai kecenderungan yang lebih besar sebagai karbon teraktif berliang mikro dan bahan penjerap yang baik untuk pemulihan surfaktan.

Kata kunci: karbon teraktif, asid fosforik, biji kurma

\section{Introduction}

The deterioration of environment in the process of economic growth has started to give impact on mankind. Lack of knowledge to deal with pollution and incapability of the natural environment to decompose unnatural generated element have made the occurrence of pollution inevitable. One of the environmental pollutions that needs to be 
made aware of is water pollution which happens because of human activities such as raw sewage discharge [1]. Raw sewage is wastewater that comes from residential areas, industries, and agricultural processes. It contains a wide variety of contaminants and can be hazardous to human and animal if untreated.

Surface-active agent or also known as surfactant is one of the common water pollutants that comes from the production of detergents, fabric softeners, emulsifiers, paints, and adhesive. It is discharged to the sewer system upon application [2]. About $50 \%$ of surfactants consumption comes from detergents and cleaners. Another source of surfactants contamination comes from surfactants dispersants for fuel oil spillages. These surfactants are resistant to bio-degradation by bacteria and have a toxic effect upon breakdown [3]. Synthetic surfactants also do not biodegrade sufficiently in the treatment plant, even when they are left for a long time [4]. Hence, the amount of surfactants must be reduced to an acceptable level before being discharged into the body of water.

Currently, there are a few techniques to remove surfactant from wastewater, which include biosorption [5], biodegradation [3], oxidation [6], adsorption [7], ultra-filtration, and ion-exchange [8]. Among these techniques, the adsorption method is easy to implement and low in cost while some of the adsorbents can be reused. Activated carbon is one of the efficient adsorbents that can be used in the adsorption method because it has a large specific surface area and $\mathrm{pH}$-independent capacity with strong carbon-surfactant interaction. The combination of a large specific surface area and $\mathrm{pH}$-independent means that activated carbon has a large adsorption capacity in order to remove the surfactants, which make it as effective adsorbents in removing surfactants from wastewater [9].

Activated carbons are carbonaceous materials characterized by their extraordinary large specific surface areas and well-developed porosity [10]. However, the commercial activated carbons are quite costly to purchase as they use high cost precursors such as petroleum residue, wood, coal, peat, and lignite that are non-renewable [11]. Hence, other sources of activated carbon such as from agricultural by-product were studied. By using agricultural byproduct, the reliance on raw materials and cost can be reduced [12]. In recent years, there is a growing research interest in the agriculture by-product that is chosen based on price, purity, potential extent of its activation and also stability of its supply such as corncob [13], rice husk [14], olive seed [15], sugarcane bagasse [16] and date seeds [17].

Date seeds are one of the lignocellulosic materials from agriculture by-products that come from the date fruit which is mostly grown in the Middle East Asia, North African, and North American desert regions [18]. Dates are composed of fleshy pericarp and seed are mostly used in the food industries to manufacture various products such as date powders, syrup, and juice, chocolate coated dates and date confectionery [19]. Upon consumption or usage for the manufacturing process, the seeds are removed from the date fruit. Hence, there is an availability to use the date stones as raw materials to produce activated carbon [20] as Malaysia has increased the number of imported dates from 7.339 to 17.756 metric tonnes from 2005 to 2015 [21].

Thus, in this study, date seeds were choose as the raw material to prepare activated carbon based on the stated criteria for surfactants recovery.

\section{Materials}

Materials and Methods

Date seeds were used as the raw material. The chemicals used in this study are $85 \%$ ortho-phosphoric acid $\left(\mathrm{H}_{3} \mathrm{PO}_{4}\right)$, cetyltrimethylammonium bromide (CTAB), TritonX-100 (TX100), deionised water, sodium hydroxide (NaOH) and distilled water.

\section{Preparation of activated carbon}

The date seeds were collected by purchasing one box of dates from the market. The date pericarps were removed to obtain the seeds used as the raw material. An amount of about $100.00 \mathrm{~g}$ of date seeds were then washed thoroughly with tap water and dried under the sunlight. Next, the date seeds were soaked with $250 \mathrm{~mL}$ of $30 \%$ aqueous solution phosphoric acid for 24 hours to give acidic conditions to the seeds (pre-treated process). Then, the date seeds were washed with distilled water and dried under room temperature [22]. 
After that, the pre-treated date seeds were impregnated with $85 \%$ of concentrated phosphoric acid with the ratio of 2:1 $(200 \mathrm{~mL}$ of phosphoric acid : $100 \mathrm{~g}$ of date seed). Next, the mixtures were heated by using a hot plate in a temperature range between $70{ }^{\circ} \mathrm{C}$ to $90{ }^{\circ} \mathrm{C}$ for 4 hours or until they appeared to be apparently semi-dried in the fume cupboard. The drying procedure was continued in the oven for 24 hours with the temperature at $110^{\circ} \mathrm{C}$ [22].

Then, the activation process was modified based on a previous study where the samples were carried out in the muffle furnace at $500{ }^{\circ} \mathrm{C}$ for two hours [17]. Lastly, the activated carbon samples were washed with distilled water and tested with the $\mathrm{pH}$ meter until it was neutral. Finally, the prepared activated carbon were kept in the desiccator and used for characterization and adsorption studies [22]. The prepared activated carbons were named as date activated carbon (DAC).

\section{Characterization of activated carbon}

DAC was characterized by FTIR (Perkin Elmer model FTIR spectrum 100) to determine the fundamental vibrations bands at mid infrared region $\left(4000-400 \mathrm{~cm}^{-1}\right)$. The Field Emission Scanning Electron Microscope with Energy Dispersive X-ray (FESEM-EDX) Spectroscopy (Hitachi SU8020) was used to examine the surface morphology and confirm the elements present in DAC. Meanwhile, multiple point nitrogen adsorptions analysis (BET) was used to determine the surface area of DAC.

\section{Adsorption capacity of activated carbon}

Cationic and non-ionic surfactants which are cetyltrimethylammonium bromide (CTAB) and TritonX-100 (TX100) were used to study the adsorption capacity onto DAC. Deionized water was used for making up the solution. About $0.5 \mathrm{~g}$ of DAC was weighed in $50 \mathrm{~mL}$ conical flasks, and then each surfactants solution was pipetted into the conical flasks, which were wrapped with parafilm and placed into an electronic bath shaker. The shaker was set at a constant speed of $100 \mathrm{rpm}$ for 2 hours. After that, the mixture was filtered and $10 \mathrm{~mL}$ of the filtrates were diluted into a $50 \mathrm{~mL}$ volumetric flask and filled up with deionized water [22]. The solutions were analysed with T80+ UV/Visible Spectrometer instrument. The concentration of CTAB was determined by measuring the UV absorbance at $\lambda_{\max } 193 \mathrm{~nm}$ while the concentration of TX100 at $\lambda_{\max } 223 \mathrm{~nm}$.

\section{Percent yield of DAC}

\section{Results and Discussion}

The product yield of the DAC from $100 \mathrm{~g}$ of raw date seeds were calculated using Equation 1 as follows:

$$
\text { Yield } \%=\frac{W_{2}}{W_{1}} \times 100
$$

where $W_{l}$ is the initial weight of date seeds $(100 \mathrm{~g})$ and $W_{2}$ is the final weight of date seeds after activation and carbonization. The percent yield of the DAC in this study was $47.12 \%$. The result of percentage yield may be affected by the impregnation ratio and activation temperature used in the preparation steps [23]. In keeping with Prahas et al., the impregnation ratio is a crucial parameter that affects the quality of the carbon. The presence of excess phosphoric acid in the impregnation process promoted gasification of char and increased the total weight loss of carbon [24]. The presence of phosphoric acid was supported by the FTIR and EDX analyses.

\section{Characterization of DAC: Fourier transfrom infrared spectroscopy}

The adsorption frequency of the raw date seeds and DAC was studied using FTIR spectrometer instrument. The spectra obtained in this study are shown in Figure 1. The functional groups present in the raw date seeds and DAC spectrum listed in Table 1.

From the raw date seed spectrum, it shows that there was a broad hydroxyl group $(\mathrm{O}-\mathrm{H})$ peak at $3375.25 \mathrm{~cm}^{-1}$ which may result from the water molecules, because date seeds contains hemicellulose and cellulose in their fiber. However, the hydroxyl peak disappeared at DAC spectrum due to loss of water moisture when the date seeds were carbonised. There was also the presence of alkanes group $(\mathrm{C}-\mathrm{H})$ peak stretch at $2924.91 \mathrm{~cm}^{-1}$ and $2851.92 \mathrm{~cm}^{-1}$. This indicated the presence of carbon and hydrogen in the date seeds. The adsorption band present at $1746.77 \mathrm{~cm}^{-1}$ was the carbonyl group $(\mathrm{C}=\mathrm{O})$, which stretch showed the presence of oxygen. Lastly, the presence of adsoption present 
peak at $1647.97 \mathrm{~cm}^{-1}$ corresponded to the $\mathrm{C}=\mathrm{C}$ double bond stretching that showed alkenes or aromatic group compound also present in the date seeds.

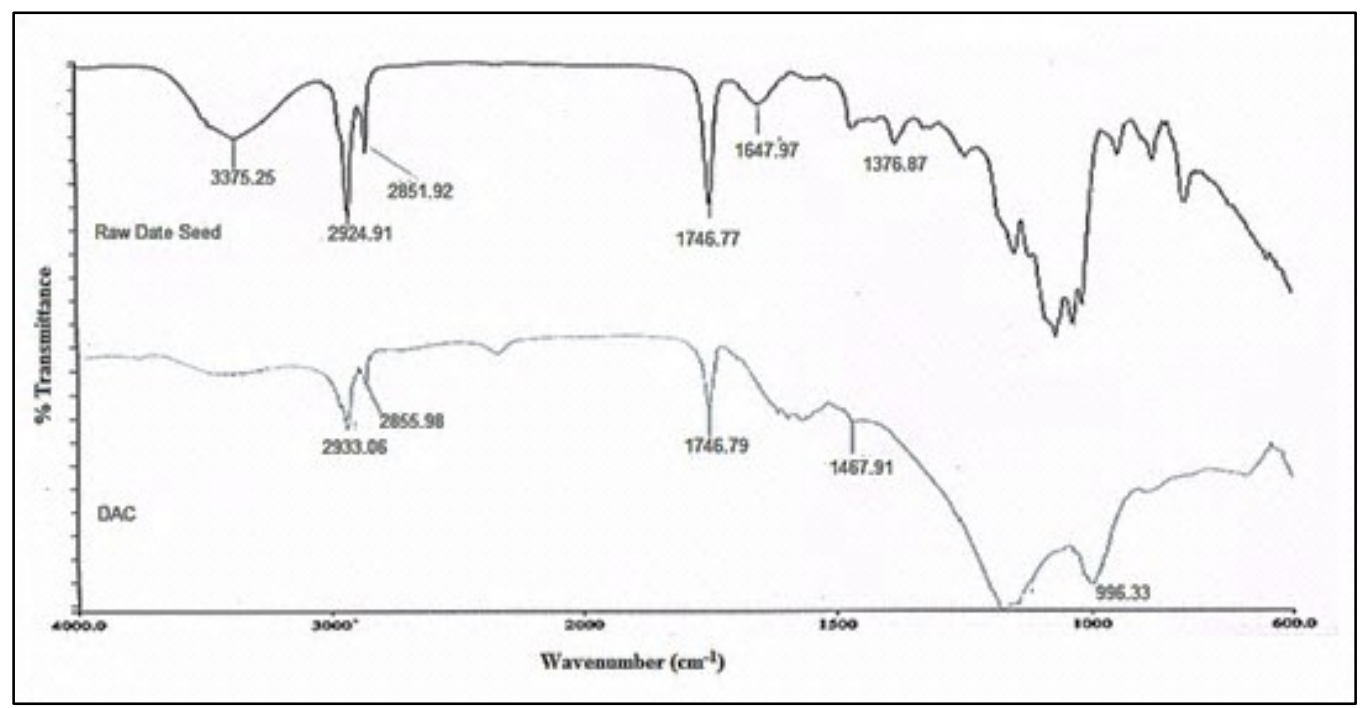

Figure 1. FTIR spectrum of raw date seed and DAC

Table 1. Functional group present in raw date seeds and DAC spectrum

\begin{tabular}{lll}
\hline Sample & Functional Group & Wavenumber $\left.\mathbf{( c m}^{-1}\right)$ \\
\hline Raw Date Seed & O-H streching & 3375.25 \\
& C-H streching & $2924.91,2851.92$ \\
& C=O streching & 1746.77 \\
& C=C streching & 1647.97 \\
& & \\
DAC & C-H streching & $2933.06,2855.98$ \\
& C $=$ O streching & 1746.79 \\
& P-O-C streching & $1467.91,996.33$ \\
\hline
\end{tabular}

The functional group of DAC showed the presence of alkanes group (C-H) stretching absorption bands at 2933.06 $\mathrm{cm}^{-1}$ and $2855.98 \mathrm{~cm}^{-1}$, respectively. The presence of carbonyl group $(\mathrm{C}=\mathrm{O})$ peak can be also seen in DAC at absorption band $1749.13 \mathrm{~cm}^{-1}$. Besides, bands at $1467.91 \mathrm{~cm}^{-1}$ and $996.33 \mathrm{~cm}^{-1}$ indicated the stretching of carbon bonded to P-O groups of phosphates [24]. The P-O functional group was present due to the use of phosphoric acid in the preparation process of activated carbon.

From the FTIR results, it is shown that the appearance and disappearance of functional groups in the raw date seeds and DAC happened due to the carbonization and impregnation process that took place at the high temperature of $500{ }^{\circ} \mathrm{C}[24]$.

Field emission scanning electron microscope

In this study, the surface morphology of the DAC was obtained from Field emission scanning electron microscope (FESEM). The micrographs of DAC sample with magnifications $1.00 \mathrm{Kx}$ and $1.50 \mathrm{Kx}$ are shown in Figures 2 (a) and 2(b), respectively. From both micrographs, the pores of DAC were shown homogenously distributed and well 
developed on the external surface. The pores are seen to be uniformly developed in the mixture of oval and circle patterns. This was due to the activation process which involved the used of phosphoric acid as an activating agent, which helped to create more pores in the activated carbon and thus increased the surface area and pores volume. These were proven by the nitrogen gas adsorption results where the surface area of DAC was $1187 \mathrm{~m}^{2} / \mathrm{g}$, which was higher compared to $682 \mathrm{~m}^{2} / \mathrm{g}$ activated carbon from date stem activated with pure steam at $450{ }^{\circ} \mathrm{C}$ [17]. Other than that, the micrographs also observe the presence of white particles inside some of the pores and scattered over the surface which are the ash [22].
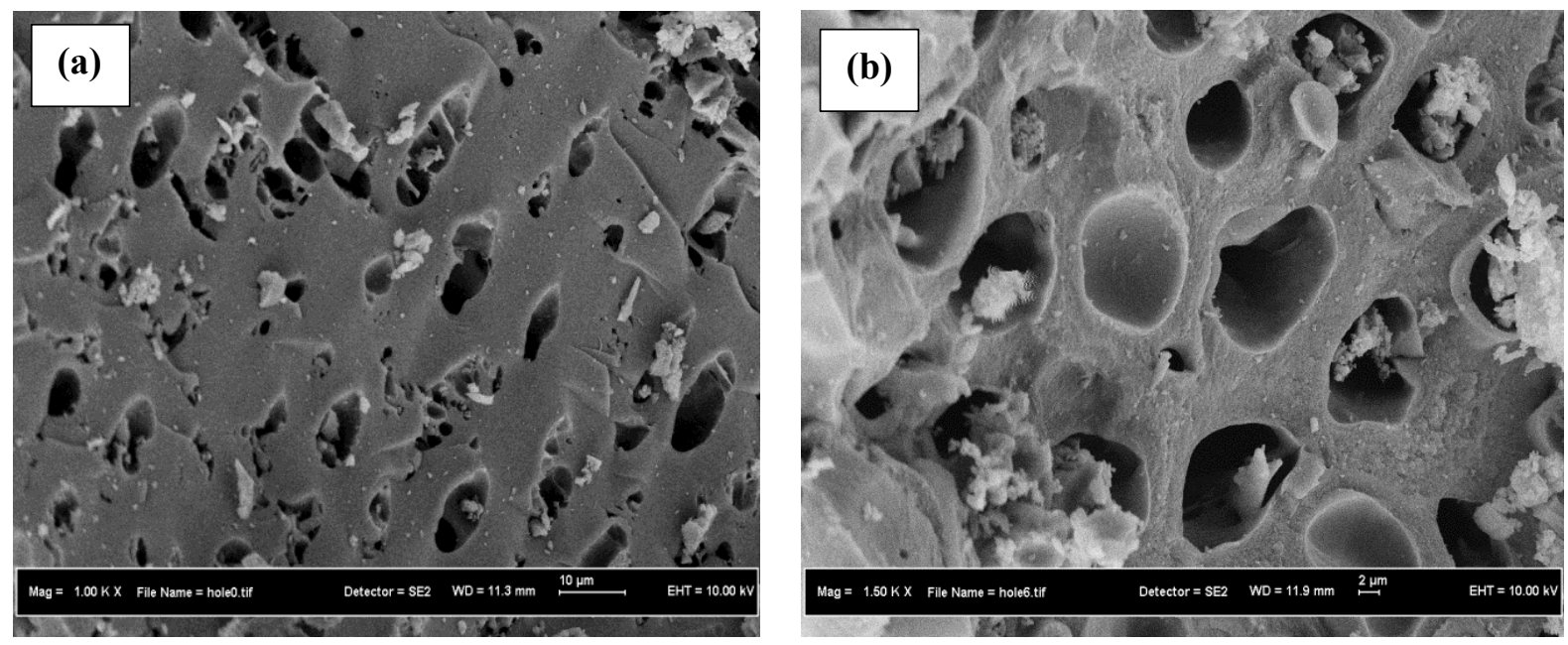

Figure 2. (a) DAC with magnification $1.00 \mathrm{Kx}$ and (b) DAC with magnification $1.50 \mathrm{Kx}$

\section{Energy dispersive X-ray spectroscopy}

In this study, Energy dispersive X-ray (EDX) was used to determine the surface composition of the DAC. The spectrum obtained from EDX is shown in Figure 3 and element percentage is summarised in Table 2. From Table 2, the presence of $79.78 \%$ carbon $(\mathrm{C}), 13.10 \%$ oxygen $(\mathrm{O})$, and $7.12 \%$ phosphorus $(\mathrm{P})$ on the surface of the DAC can be seen. The high percentage of carbon indicated that the volatile organic compounds in the date seeds were reduced and resulted in char containing a higher content of fixed carbon [11]. Phosphorus element was present on the DAC due to the activating agent used in this study which was phosphoric acid. This indicated that phosphorus compounds were strongly bound to the oxygen and carbon and therefore not easily removed by washing, either with the cold or hot distilled water [17].

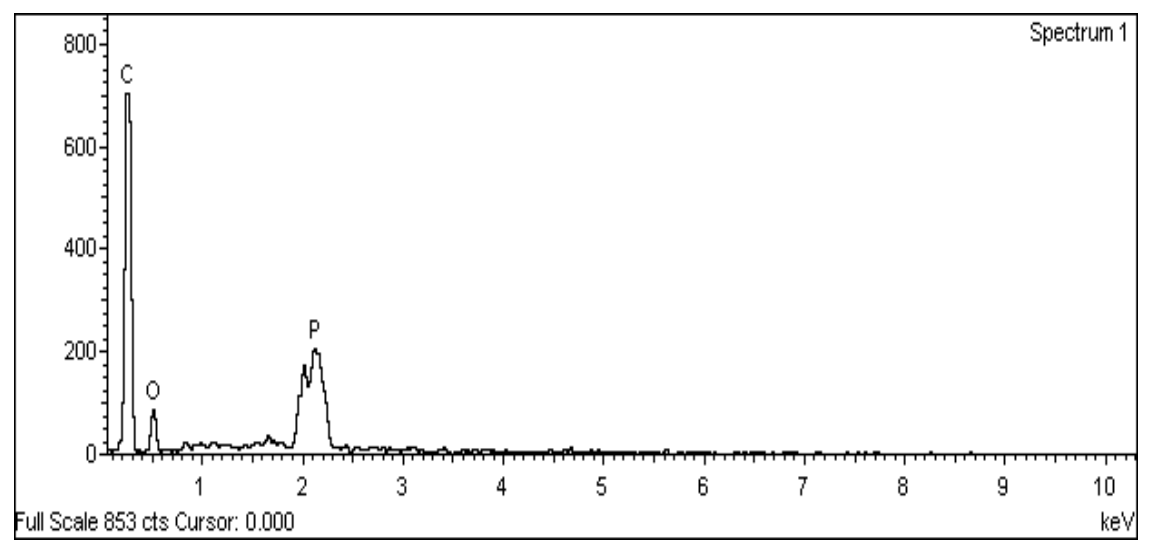

Figure 3. EDX spectrum for DAC 
Table 2. Composition of elements presence on the DAC surface

\begin{tabular}{|c|c|c|}
\hline \multirow[t]{2}{*}{ Element } & \multicolumn{2}{|c|}{ Weight Percentage (\%) } \\
\hline & Weight & Atomic \\
\hline Carbon & 79.78 & 86.37 \\
\hline Oxygen & 13.10 & 10.64 \\
\hline Phosphorus & 7.12 & 2.99 \\
\hline
\end{tabular}

\section{Nitrogen gas adsorption analysis}

The solid-gas adsorption study was determined using BET surface area model and adsorption isotherm. The BET surface area $\left(\mathrm{S}_{\mathrm{BET}}\right)$ was carried out by using nitgogen gas analysis at $77 \mathrm{~K}$. The results are shown in Table 3 .

Table 3. The specific surface area, average pores diameter and total pores volume of DAC

\begin{tabular}{lccc}
\hline Sample & $\begin{array}{c}\text { Specific surface area, } \\
\boldsymbol{S}_{\boldsymbol{B E T} T}\left(\mathbf{m}^{2} / \mathbf{g}\right)\end{array}$ & $\begin{array}{c}\text { Total pores volume, } \\
\boldsymbol{V}\left(\mathbf{c m}^{\mathbf{3}} / \mathbf{g}\right)\end{array}$ & $\begin{array}{c}\text { Average pores diameter, } \\
\boldsymbol{d}(\boldsymbol{\AA})\end{array}$ \\
\hline $\mathrm{DAC}$ & 1187 & 0.482 & 16.21 \\
\hline
\end{tabular}

From the results, the $S_{B E T}$ of the DAC activated by $\mathrm{H}_{3} \mathrm{PO}_{4}$ was high which was $1187.6844 \mathrm{~m}^{2} / \mathrm{g}$ compared to the date seeds that used other activation agents such as ferric chloride $\left(780 \mathrm{~m}^{2} / \mathrm{g}\right)[25]$ and calcium acetate $\left(702 \mathrm{~m}^{2} / \mathrm{g}\right)$ [26]. This indicated that $\mathrm{H}_{3} \mathrm{PO}_{4}$ was a good activating and dehydrating agent as the process of dehydrating the raw material helped in the development of the higher surface area by penetrating deep into the raw material. The total pores volume of the DAC was $0.482 \mathrm{~cm}^{3} / \mathrm{g}$ with the average pores diameter of $16.21 \AA$, indicating that micropores were present $(d<20 \AA)$ [27].

The adsorption isotherm result for DAC is shown in Figure 4. From the results, it is shown that the physisorption isotherm was Type I isotherm, also known as Langmuir isotherm according to IUPAC classification [27]. The isotherm showed that the adsorption was reversible and the amount of gas adsorbed was approaching the limiting value as $\mathrm{P} / \mathrm{P}_{\mathrm{o}} \rightarrow 1$. This indicated that the $\mathrm{DAC}$ consisted of micropores with a micropores filling mechanism.

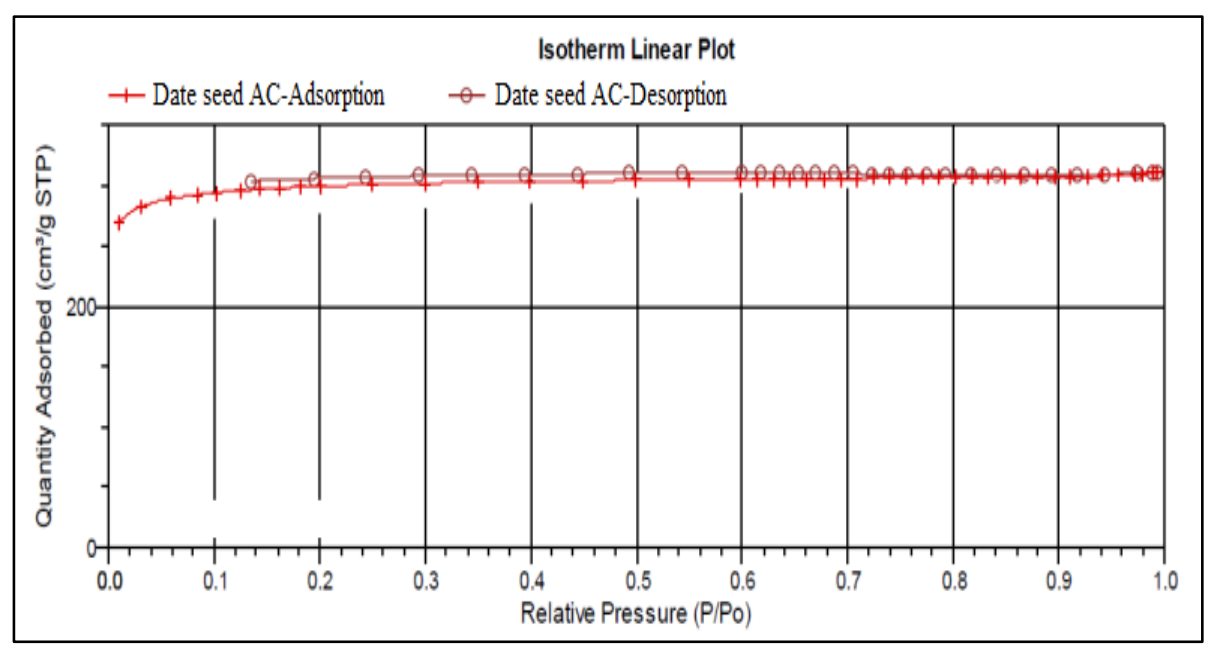

Figure 4. Adsorption isotherm of DAC 
Based on the pores size distribution graph (Figure 5), DAC sample also had macropores represented by a small shoulder peak in between pore width of $50 \AA$ to $60 \AA$ [27]. This result can be explained by the activation process where the phosphoric acid used can enhance and produce relatively large pores [28]. It was revealed that DAC exhibited a well-developed porous network structure which contained macropores. This porosity is an advantage for DAC where large sized pores will act as feeder during the adsorption process [17].

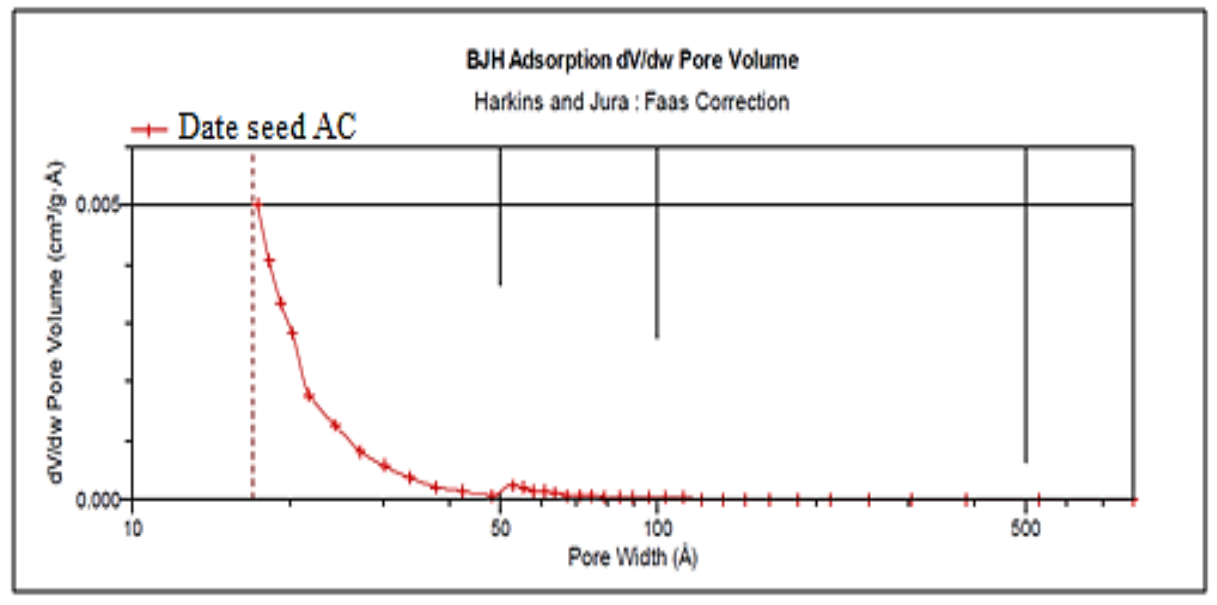

Figure 5. Pores size distribution plot of DAC

\section{Adsorption capacity of activated carbon}

In this adsorption study, two types of surfactants were used, namely CTAB and TX-100. Both adsorptions were performed at room temperature $\left(28^{\circ} \mathrm{C}\right)$. The adsorption capacities of DAC for both surfactants are shown in Table 4 .

Table 4. Adsorption capacity of CTAB and TX-100 onto DAC

\begin{tabular}{lcc}
\hline Type of surfactants & $\begin{array}{c}\text { Adsorption capacity, } \\
\mathbf{q}_{\mathbf{e}}(\boldsymbol{x} / \boldsymbol{m})\end{array}$ & $\begin{array}{c}\text { Adsorption's percentage } \\
\mathbf{( \% )}\end{array}$ \\
\hline CTAB & $23.0724 \mathrm{mg} \mathrm{g}^{-1}$ & 92.33 \\
TX-100 & $11.3868 \mathrm{mg} \mathrm{g}^{-1}$ & 95.63 \\
\hline
\end{tabular}

From the results, it is shown that CTAB adsorption capacity was higher (23.0724 $\mathrm{mg} \mathrm{g}^{-1}$ ) compared to TX-100 $\left(11.3868 \mathrm{mg} \mathrm{g}^{-1}\right)$. The difference in the adsorption capacity could be due to the charge of the surfactants. CTAB carried positively charged hydrophilic part which could be easily attracted and adsorbed to the surface of negatively DAC. The DAC was supported by the EDX result which consisted of phosphorus element that carried the $\mathrm{P}^{3-}$ charge from phosphoric acid, $\mathrm{H}_{3} \mathrm{PO}_{4}$. This phenomenon explained that CTAB molecules formed a monolayer coverage on DAC surface at equilibrium through the van der Waal's forces (electrostatic forces) [29]. Nevertheless, the low adsorption capacity of TX-100 was because it is a non-ionic surfactant that not carry any charged on the hydrophilic part. Thus, TX-100 is difficult to adsorb on a charged surface. However, in order to increase the adsorption of TX100 onto the surface, it needs enough energy adsorption force such as increasing the temperature to overcome the strong interaction of water molecules with DAC surface [30].

\section{Conclusion}

According to all the data obtained, date seeds could be a good precursor in order to prepare an activated carbon. The preparation of DAC by using the high concentration of phosphoric acid $(85 \%)$ with the ratio $2: 1$ as the chemical activating agent at low activation and carbonization temperature $\left(500^{\circ} \mathrm{C}\right)$ contributed a well-developed porosity. 
Apart from that, DAC showed a high surface area from this method of preparation. Thus, these characteristics directly enhanced the adsorption process of surfactants onto DAC, especially for CTAB due to the electrostatic force. Therefore, activated carbon prepared from date seeds (DAC) has shown its availability to be a good adsorbent in surfactant recovery.

\section{Acknowledgements}

The authors would like to acknowledge the Department of Chemistry at the Faculty of Applied Sciences, Universiti Teknologi MARA Kuala Pilah Campus, Negeri Sembilan for the facilities provided, as well as all the students and laboratory staff for their continuous help.

References
1. Hitam, M. B. and Borhan, H. B. (2012). FDI, growth and the environment: Impact on quality of life in Malaysia. Procedia - Social and Behavioral Sciences, 50: 333 - 342.

2. Clara, M., Scharf, S., Scheffknecht, C. and Gans, O. (2007). Occurrence of selected surfactants in untreated and treated sewage. Water Research, 41(19): 4339 - 4348.

3. Scott, M. J. and Jones, M. N. (2000). The biodegradation of surfactants in the environment. Biochimica et Biophysica Acta (BBA) - Biomembranes, 1508 (1-2): 235 - 251.

4. Harwell, J. H., Sabatini, D. A. and Knox, R. C. (1999). Surfactants for ground water remediation. Colloids and Surfaces A: Physicochemical and Engineering Aspects, 151: 255 - 268.

5. Aksu, Z. (2005). Application of biosorption for the removal of organic pollutants: A review. Process Biochemistry, 40 (3-4): 997 - 1026.

6. Zsilák, Z., Fónagy, O., Szabó-Bárdos, E., Horváth, O., Horváth, K., and Hajós, P. (2014). Degradation of industrial surfactants by photocatalysis combined with ozonation. Environmental Science and Pollution Research, 21(19): $11126-11134$.

7. Schouten, N., Van Der Ham, L. G. J., Euverink, G-J. and Haan, A. B. (2007). Selection and evaluation of adsorbents for the removal of anionic surfactants from laundry rinsing water. Water Research, 41: 4233 - 4241.

8. Kowalska, I. (2008). Surfactant removal from water solutions by means of ultrafiltration and ion-exchange. Desalination, 221: 351 - 357.

9. Krivova, M. G., Grinshpan, D. D. and Hedin, N. (2013). Adsorption of CnTABr surfactants on activated carbons. Colloids and Surfaces A: Physicochemical and Engineering Aspects, 436: 62 - 70.

10. Al-Qodah, Z. and Shawabkah, R. (2009). Production and characterization of granular activated carbon from activated sludge. Brazilian Journal of Chemical Engineering, 26: 127 - 136.

11. Yahya, M. A., Al-Qodah, Z. and Ngah, C. W. Z. (2015). Agricultural bio-waste materials as potential sustainable precursors used for activated carbon production: A review. Renewable and Sustainable Energy Reviews, 46: 218 - 235.

12. Qin, C., Chen, Y. and Gao, J. M. (2014). Manufacture and characterization of activated carbon from marigold straw (Tagetes erecta L) by $\mathrm{H}_{3} \mathrm{PO}_{4}$ chemical activation. Materials Letters, 135: 123 - 126.

13. Song, M., Jin, B., Xiao, R., Yang, L., Wu, Y., Zhong, Z. and Huang, Y. (2013). The comparison of two activation techniques to prepare activated carbon from corn cob. Biomass and Bioenergy, 48: 250 - 256.

14. Cheenmatchaya, A. and Kungwankunakorn, S. (2014). Preparation of activated carbon derived from rice husk by simple carbonization and chemical activation for using as gasoline adsorbent. International Journal of Environmental Science and Development: $171-175$.

15. Nouri, H. and Ouederni, A. (2013). Modeling of the dynamics adsorption of phenol from an aqueous solution on activated carbon produced from olive stones. International Journal of Chemical Engineering and Applications, 4(4): $254-261$.

16. Amin, N. K. (2008). Removal of Reactive Dye from Aqueous Solutions by Adsorption onto Activated Carbons Prepared from Sugarcane Bagasse Pith. Desalination, 223(1-3): 152 - 161.

17. Hadoun, H., Sadaoui, Z., Souami, N., Sahel, D. and Toumert, I. (2013). Characterization of mesoporous carbon prepared from date stems by $\mathrm{H}_{3} \mathrm{PO}_{4}$ chemical activation. Applied Surface Science, 280: $1-7$.

18. Danish, M., Hashim, R., Ibrahim, M. N. M. and Sulaiman, O. (2014). Optimized preparation for large surface area activated carbon from date (Phoenix dactylifera L.) stone biomass. Biomass and Bioenergy, 61: $167-178$.

19. Rahman, M. S., Kasapis, S., Al-Kharusi, N. S. Z., Al-Marhubi, I. M. and Khan, A. J. (2007). Composition characterisation and thermal transition of date pits powders. Journal of Food Engineering, 80: 1 - 10. 
20. Haimour, N. M. and Emeish, S. (2006). Utilization of date stones for production of activated carbon using phosphoric acid. Waste Management, 26: 651 - 660.

21. The International Nut and Dried Fruit Council Foundation (INC). (2017). Nuts \& Dried Fruits Statistical Yearbook 2016/2017. pp 56.

22. Jamion, N. A and Mohamed, S. M. (2014). Characterization of activated carbon from sugar cane husk. Applied Mechanics and Materials, (699): 1006 - 1011.

23. Demiral, I. and Aydin Ş. C. (2016). Preparation and characterisation of activated carbon from pumpkin seed shell using $\mathrm{H}_{3} \mathrm{PO}_{4}$. Anadolu University Journal of Science and Technology-A Applied Sciences and Engineering, 17(1): 125 - 138 .

24. Prahas, D., Kartika, Y., Indraswati, N. and Ismadji, S. (2008). Activated carbon from jackfruit peel waste by $\mathrm{H}_{3} \mathrm{PO}_{4}$ chemical activation: Pore structure and surface chemistry characterization. Chemical Engineering Journal, 140(1-3): $32-42$.

25. Theydan, S. K. and Ahmed, M. J. (2012). Adsorption of methylene blue onto biomass-based activated carbon by $\mathrm{FeCl}_{3}$ activation: Equilibrium, kinetics, and thermodynamic studies. Journal of Analytical and Applied Pyrolysis, 97: 116 - 122.

26. Awwad, N. S., El-Zahhar, A. A., Fouda, A. M. and Ibrahium, H. A. (2013). Removal of heavy metal ions from ground and surface water samples using carbons derived from date pits. Journal of Environment Chemical Engineering, 1: $416-423$.

27. International Union of Pure and Applied Chemistry (1994). Recommendations for the characterization of porous solids. Pure and Applied Chemistry, 66(8): 1739 - 1758.

28. Puziy, A. M., Poddubnaya, O. I., Martinez-Alonso, A., Suarez-Garcia, F. and Tascon, J. M. D. (2002). Synthetic carbons activated with phosphoric acid, porous structure. Carbon, 40: $1507-1519$.

29. Martinez-Costa, J. I. and Leyva-Ramos, R. (2017). Effect of surfactant loading and type upon the sorption capacity of organobentonite towards pyrogallol. Colloids and Surfaces A: Physicochemical Engineering Aspects, 520: $676-685$.

30. Huang, L., Maltesh, C. and Somasundaran, P. (1996). Adsorption behavior of cationic and nonionic surfactant mixtures at the alumina-water interface. Journal of Colloid and Interface Science, 177: 222 - 228. 